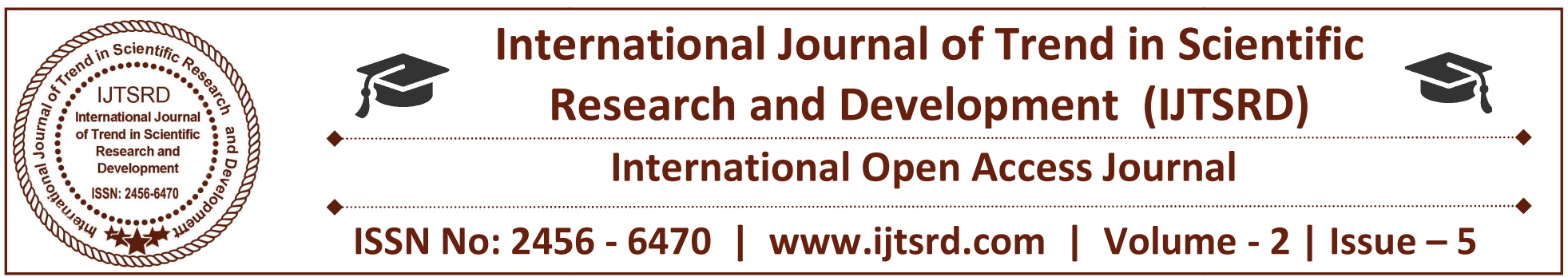

\title{
Transfer of Risk in International Sale
}

\author{
Aastha Srivastava \\ B.A., LL.B , Indore Institute of Law \\ Indore, Madhya Pradesh, India
}

\section{INTRODUCTION}

The general rule prevalent in India is that the risk of damage or loss of movable property lies with the owner of the good. The Latin term 'res perit domino' expresses that the thing is lost to the owner of the property. This principle is applicable in the case of sale of movable property. The movable property includes every kind of movable property, including stocks and shares, growing crops, grass, and things attached to or forming part of the land that is agreed to be severed before sale or under the contract of sale. It does not apply to actionable claims and money. ${ }^{1}$ The barter or exchange of goods is not covered under this Act as it is governed by the general provisions of the Indian Contract Act, $1872{ }^{2}$

India is party to both the International laws i.e. UN Convention on contracts for the International Sale of Goods $1980^{3}$ and Convention for the Unification of certain Rules for International Carriage by Air 1999 (Montreal Convention).

\section{LITERATURE REVIEW}

Ingeborg Schwenzer, Pascal Hachem and Christopher Kee in their book "Global Sales and Contract Law" has beautifully This work encompasses all aspects of a sale of goods transaction and takes a wide view of sale by including general contract law. James M. Klotz in his book "International Sales Agreements: An Annotated Drafting and Negotiating Guide" has described the process of drawing up sound agreements for the international sale of goods.

\footnotetext{
${ }^{1}$ Sales of Goods Act, Section 2(7)(1930)

${ }^{2}$ Indian Contract Act (1872)

${ }^{3}$ International Sale of Goods (1980)
}

\section{OBJECTIVE OF THE STUDY}

The purpose of this study is to find the transfer of risk $\mathrm{n}$ international sale and the domestic legislation and international rules apply to sale of goods contract in local jurisdiction.

\section{RESEARCH METHODOLOGY}

During this paper the researcher will follow Doctrinal research methodology. This type of research is also known as pure. Also content analysis of available both primary and secondary data but mostly of secondary data.

\section{RESEARCH QUESTIONS}

1. What domestic legislation and international rules apply to a sale of goods contract in local jurisdiction?

2. Are standard international contractual terms commonly used?

3. "Does the CISG (Contracts for the International Sale of Goods) 1980 adequately protect the interests of an 'innocent' party where the other party is in breach of contract?

\section{DOMESTIC LEGISLATION}

The domestic legislation applicable to a sale of goods contract in India is the Sale of Goods Act 1930 $(\mathrm{SGA})^{4}$. The SGA is applicable to all transactions involving the sale of goods within the territory of India.

The SGA was drafted and prepared on the model of the English Sale of Goods Act 1893. The provisions relating to the sale of goods used to be part of the Indian Contract Act $1872^{5}$, but were repealed after the

\footnotetext{
${ }^{4}$ Sales of Goods Act (1930)

${ }^{5}$ Supra 2
} 
SGA came into force. Sections that were not repealed after the promulgation of the SGA remain in force, provided that they are not inconsistent with any provisions of the SGA. ${ }^{6}$

While the SGA does not grant any specific rights to smaller businesses, small business set ups are protected under the Micro, Small and Medium Enterprises Development Act $2006^{7}$ (MSME Act). A company incorporated in India may qualify as a micro, small or medium enterprise if it satisfies the criteria set out in section 2 of the MSME Act.

A dispute involving an MSME must first be subject to conciliation and, if conciliation fails, to arbitration (section 18(2), MSME Act). Both conciliation and arbitration must be conducted in accordance with the Arbitration and Conciliation Act $1996 .{ }^{8}$

\section{Section 26 of Sales of Goods Act}

Section 26 of the Sale of Goods Act, 1930 states the goods are the owner's risk if the property has not been transferred to the buyer. But if the property has been transferred to the buyer then the goods are buyer's risk. This provision is applicable if no specific provision has been signed by the parties to the contract in their contract regarding this. This rule is applicable irrespective of the fact that delivery has been made or not.

It means that the risk is associated with ownership and not with mere possession of the property. To decide whether the risk has been passed or not, we first need to find whether the property in goods i.e. the ownership has passed or not. ${ }^{9}$

The passing of risk means the transfer of the liability for damage or loss of the property from the seller of the immovable property to the buyer. The risk in the property prima facie passes with the property, but if the parties to the contract agree to pass the risk on the property at some other level of transaction, then that is also possible, depending upon the terms of their contract. It is also possible that that the title, risk, and possession of the property pass independent of each

\footnotetext{
${ }^{6}$ Sales of Goods Act, Section 3 (1930)

${ }^{7}$ Micro, Small and Medium Enterprises Development Act (2006)

${ }^{8}$ Arbitration and Conciliation Act (1996).

${ }^{9}$ Sunidhi, Transfer of Risk under the Sale of Goods Act (July 11, 5:10 PM), https://blog.ipleaders.in
}

other from the seller to the buyer in a sale's transaction. ${ }^{10}$

But international sales transactions differ widely from the established concepts of national sales law. The UN Sales Convention made a fresh start on the passing of risk problem with an original approach differing remarkably from conventional wisdom, yet trying to be close to practical needs.

\section{International rules}

India is a party to both the:

> UN Convention on Contracts for the International Sale of Goods 1980 (CISG).

Convention for the Unification of Certain Rules for International Carriage by Air 1999 (Montreal Convention).

Most agreements involving an Indian party and a foreign counterparty refer to the CISG, as it covers international sales of goods.

Contracts in the aviation sector refer to the provisions of the Montreal Convention. These contracts usually:

$>$ Provide that, where a journey involves an ultimate destination or a stop in a country other than the country of departure, the Montreal Convention or its predecessor (the Warsaw Convention), including its amendments, apply to the entire journey.

Limit the liability of carriers for death or personal injury and in respect of loss of, or damage to, baggage. ${ }^{11}$

\section{STANDARD CONTRACTUAL TERMS}

Certain contracts executed by Indian parties refer to the International Chamber of Commerce international commercial terms (Incoterms) 2010 or the Uniform Customs and Practice for Documentary Credits. The Indian courts recognize agreements that provide for the application of these standard contractual terms.

\section{Substantive requirements}

A contract for the sale of goods is created when an offer to buy or sell goods is made for a price, and when that offer is accepted (section 5, Sale of Goods Act 1930 (SGA)). A contract for the sale of goods can provide for the immediate or future delivery of goods, and for payment of the price at once or in instalments.

\footnotetext{
${ }^{10}$ Sanjay Notani, Sale and Storage of Goods in India (July 11, 2018, 4:31 PM), https://uk.practicallaw.thomsonreuters.com ${ }^{11}$ ibid
} 
Section 2 of the SGA contains the definitions of the terms "seller", "property", "goods", "buyer" and "price".

Any contract entered into in India, for the sale of goods or otherwise, must satisfy the criteria laid down in section 10 of the Indian Contract Act 1872. A valid contract must be entered into by parties capable of entering into a contract, have a lawful object, a lawful consideration and must be enforceable under Indian law.

\section{Formal requirements}

A contract for the sale of goods can be concluded in writing or orally (or partly in writing and orally) and can also arise from the conduct of parties.

\section{Language requirements}

The SGA does not provide that a sale of goods contract must be in a particular language. However, the relevant High Court rules and the Supreme Court rules provide that pleadings must be filed in English. Therefore, if a dispute involving a sale of goods contract is brought before these courts for adjudication, the contract will need to be translated into English.

English is used in most instances where an Indian party executes an international sale of goods contract.

\section{Registration requirements}

The registration of any instrument that purports or operates to create, declare, assign, limit or extinguish any right, title or interest to or in movable property, is optional (section 18(d), Registration Act 1908) ${ }^{12}$. Therefore, registration of a sale of goods contract (which necessarily involves movable property) is optional.

\section{Price, Payment and Delivery}

The price in a sale of goods contract can be:

$>$ Fixed in the contract itself.

$>$ Agreed to be determined in a manner agreed by the parties, or which may be agreed upon during the course of the transaction.

Where the contract does not mention a price, the buyer must pay a "reasonable price" to the seller (Sale

\footnotetext{
${ }^{12}$ Registration Act 1908, Section 18(d), “instruments (other than wills) which purport or operate to create, declare, assign, limit or extinguish any right, title or interest to or in movable property"
}

of Goods Act $1930(\mathrm{SGA}))^{13}$. The reasonable price must be determined on the basis of the circumstances of each case.

The SGA does not provide that the price must be in a particular currency. The parties are therefore free to agree on any currency.

The Indian courts can issue a decree in a foreign currency if the following criteria are met:

$>$ The claimant must request a decree ordering the defendant to pay him or her sum in a foreign currency that is claimed in the plaint.

$>$ The claimant must convert the value of the claim in the Indian currency, for the purpose of court fees, at the rate of exchange prevailing on the date of filing of the suit, and pay the court fees.

$>$ The claimant must give an undertaking in the plaint that it will make good any deficiency in the court fees if at the date of judgment, at the rate of exchange then prevailing, the Indian rupee equivalent of the foreign exchange sum decreed is higher than that mentioned in the plaint.

The SGA does not stipulate the time for payment or the mode of payment. The parties are free to agree on the period of credit and the method of payment in the contract (including payment by way of letter of credit, promissory note, fund transfer or cash payment).

However, the regulations issued under the Foreign Exchange Management Act 1999, including those relating to the import and export of goods, provide for a maximum period of credit and for the method of payment in sales of goods.

Delivery means voluntary transfer of possession from one person to another (Sale of Goods Act 1930 (SGA)).

The seller has a duty to deliver the goods and the buyer has a duty to accept the goods, in accordance with the terms and conditions agreed to between them (SGA).

\section{Time of delivery}

The goods must be delivered at the time agreed to between the parties. When the parties have not agreed on the time of delivery, the seller must deliver the goods within a reasonable time (section 36(2), SGA).

\footnotetext{
${ }^{13}$ Supra 4
} 
"Reasonable time" must be determined in accordance with the facts and circumstances of each case.

\section{Place of delivery}

Subject to any provision to the contrary, the goods must be delivered at the place where they were either (section 36(1), SGA) $)^{14}$

$>$ At the time of sale.

$>$ At the time the agreement to sell was entered into.

If the goods do not exist at the time of the agreement, they must be delivered at the place where they will be manufactured or produced.

\section{ENFORCEMENT AND REMEDIES Quality and fitness for purpose}

There is generally no implied condition on quality or fitness of goods sold for any particular purpose (section 16, Sale of Goods Act 1930 (SGA)). However, there is an implied condition that the goods are fit for a particular purpose if the following conditions are met:

$>$ The buyer has made known to the seller the purpose of his or her purchase.

$>$ The buyer relied on the skill and judgement of the seller to select the best goods.

> The seller is ordinarily dealing in those goods.

There is no implied condition on fitness for purpose if the goods were sold under a trade mark or a patent name.

\section{Description}

When goods are sold by description, there is an implied condition that the goods supplied must correspond to the description (section 15, SGA).

\footnotetext{
${ }^{14}$ Sales of Goods Act, Section 36(2)"Whether it is for the buyer to take possession of the goods or for the seller to send them to the buyer is a question depending in each case on the contract, express or implied, between the parties. Apart from any such contract, goods sold are to be delivered at the place at which they are at the time of the sale, and goods agreed to be sold are to be delivered at the place at which they are at the time of the agreement to sell or if not then in existence, at the place at which they are manufactured or produced."(1930)
}

\section{Liability of the seller}

If a contract for the sale of goods contains a condition that is essential for the main purpose of the contract, the innocent party can repudiate the contract if this condition is breached (section 12, SGA). In the event of a breach of a warranty that is collateral to the main purpose of the contract, the innocent party has a right to claim damages.

Whether a particular term is a condition or warranty depends on the construction of the contract.

The remedies available for breach of a sale of goods contract are:

$>$ Suit for damages.

$>$ Suit for price.

$>$ Suit for interest.

A buyer who suffers a loss due to a breach of warranty cannot reject the goods, but can either (section 59, Sale of Goods Act 1930):

$>$ Claim for a reduction or extinction of the price.

$>$ Sue the seller for damages.

The innocent party can only seek compensation for losses that the parties knew, at the time of entering into the contract, to be likely to result from a breach of the contract.

The court can issue an order of specific performance to prevent the other party from breaching the provisions of the contract in certain circumstances. For example, the buyer may be able to file a complaint for sale of defective goods and seek specific performance under the Consumer Protection Act 1986.

The general law on contractual remedies is the Specific Relief Act 1963 (SRA). Under the SRA, "goods" means every kind of movable property other than actionable claims and money, and includes stock and shares, growing crops, grass, and things attached to, or forming part of, the land that are agreed to be severed before the sale or under the contract of sale. Specific performance of a contract involving movable property will only be granted when either (section 10, SRA):

$>$ The property is not an ordinary article of commerce, is of special value or interest to the claimant, or consists of goods that are not easily obtainable in the market. 
$>$ The property is held by the defendant as the agent or trustee of the claimant.

A buyer has the following remedies:

$>$ Damages for non-delivery.

$>$ Specific performance. A suit for specific performance can only be allowed if an award of damages would be insufficient, when the goods are unique and costly and can be ascertained.

$>$ Suit for breach of warranty. Where the seller has breached a warranty, or the buyer elects to treat a breach of condition as a breach of warranty, the buyer is not entitled to reject the goods. However, the buyer can:

$>$ claim for a reduction or extinction of the price; or

$>$ sue the seller for damages.

$>$ Damages, in the event of repudiation of the contract by the seller before the due date.

$>$ Suit for interest.

When the property in the goods has passed to the buyer, the seller has:

$>$ A lien over the goods.

$>$ A right to stop the goods during transit.

$>$ A right of resale.

When the property has not passed to the buyer, the seller has the same rights as above and the right to withhold delivery.

The seller can also file a suit against the buyer for the price, damages and interest.

\section{Exclusion of liability}

The parties can contractually exclude certain liabilities. The parties cannot exclude liability for fraud, coercion, unlawful purpose and criminal liability.

\section{Choice of law}

The Sale of Goods Act 1930 (SGA) applies to the whole of India (section 1, SGA). Therefore, any sale of goods contract executed in India, the application of which is limited to the territory of India, is governed by the SGA, even if the agreement provides for a foreign governing law.

The parties are free to decide on the law governing a sale of goods contract if one of the parties is based in another jurisdiction. However, the capacity of an
Indian party to enter into a contract is always governed by the laws of India.

Where both parties are located in India and the contract must be performed in India, the Indian courts will apply the Sale of Goods Act 1930 for ruling on any dispute that may arise between the parties.

\section{Choice of jurisdiction}

The Indian courts will give effect to a choice of foreign jurisdiction when one of the parties is not based or incorporated in the territory of India.

If the parties do not make a choice of jurisdiction, the claimant can sue the defendant at the place where (section 20, Code of Civil Procedure 1908):

$>$ The defendant resides.

$>$-The cause of action has arisen.

The last known place of business of the defendant is located.

\section{INTERNATIONAL ASPECT OF TRANSFER OF RISK IN SALE}

\section{What Is The CISG?}

There are a number of conventions which relate to the international sale of goods including the United Nations Convention on the Limitation Period in the International Sale of Goods 1974, the International Institute for the Unification of Private Law (UNIDROIT) Convention on Agency in the International Sale of Goods 1983, and the United Nations Commission on International Trade Law (UNCITRAL) Model Law on Procurement of Goods, Construction and Services 1994.

The United Nations Convention on Contracts for the International Sale of Goods $1980^{15}$ (CIGS) is the main convention for the International Sale of Goods. The CISG is an international set of rules designed to provide clarity to most international sales transactions involving the sale of goods. The CISG went into effect on January 1, 1988, with the United States as a party. Most Western countries are now signatories to the CISG. The CISG can be both a discretionary and mandatory set of rules. It is discretionary when both parties agree to be bound by its rules; it has mandatory application when the parties do not choose to use it but become bound to it by virtue of its automatic application. As a result of the mandatory

\footnotetext{
${ }^{15}$ Contracts for the International Sale of Goods (1980)
} 
application of the CISG, most international sale of goods contracts with parties in western countries will be subject to the CISG, unless specifically excluded in accordance with the CISG's terms.

The purpose of the CISG is to make it easier and more economical to buy and sell raw materials, commodities and manufactured goods in international commerce. Without the Convention, there is greater room for uncertainty and disputes. The trading law of one country often differs from that of another. In international transactions, there is often doubt about which nation's law is in control. Where there is doubt about the rules that apply, the parties cannot be sure of their rights and obligations. Such uncertainty breeds inefficiency and mistrust.

The CISG does not deprive parties to the contract of the freedom to form their contracts to their specifications. Generally, the parties are free to modify the rules established by the Convention or to agree that the Convention is not to apply at all.

Domestic law also affects the International Sale of Goods provided that no inconsistency arises between the application of these domestic laws and the performance of the country's obligations under any international conventions: InWilliams $v$ The Society of Lloyd's and Hi-Fert Pty ltd $v$ Kiukiang Maritime Carriers Inc. ${ }^{16}$

\section{Protection ofan 'Innocent' Party underthe CISG}

Both buyer and seller have certain protections under the CISG.

The seller's remedies under the CISG are expressed in a number of categories including; requesting the buyer to perform his or her contractual obligations under Art 62., fixing an additional period of time for the buyer to perform under Art 63; requesting 'specific performance' under Arts 28 and 62; declaring the contract avoided under Art 64; suspending the performance of the contract under Art 71; avoiding the contract on the ground of an anticipatory breach under Art 72; and claiming damages under Arts 74-78.

The buyer's remedies under the Convention can be divided into the following categories; requesting the seller to perform his or her contractual obligations under Art 46; fixing an additional period of time for the seller to perform under Art 47; requesting a court to order specific performance under Arts 28 and 46; declaring the contract avoided under Art 49; reducing the price of the non-conforming goods under Art 50; refusing to take an earlier delivery under Art 51; refusing to take delivery of a greater (or lesser) quantity under Art 52; suspending the performance of a contract under Art 71; avoiding a contract on the ground of an anticipated fundamental breach under At 72; avoiding a contract in proportion to the defective installments under 73; and claiming damages and interest under arts 74-78.

For the international sales of goods under the CISG, the buyer must examine the goods within as short a period of time as is practicable in the circumstances and give the seller notice of any non-conformity with the quality, quantity, description and other CISG requirements. If the breach is fundamental, the buyer may declare the contract avoided. The buyer may also require the seller to remedy the lack of conformity or fix an additional period of time for performance of the seller's obligations (these remedies being in addition to an action for breach of contract). If goods do not conform, the buyer may accept the goods and reduce the price proportionately.

If the seller delivers a quantity of goods greater than the contract quantity, the buyer may take or refuse delivery of the excess. Any part of the excess taken must be paid for at the contract price. ${ }^{17}$

\section{CONCLUSION}

Transfer of risk determines who bears the risk on the goods if it is lost or damaged. Hence the consequences of this concept hold an important place where two parties are contracting. The consequences, the timing, and the process of transfer of risk possess many interesting questions and make it an interesting study.

The principle has been dealt in different ways in different legal systems. We live in an era where the unification of International law is being sought. This goal can only be achieved when we have a clear understanding of different legal systems and come to a draft which comprises of the best of all and thus acceptable to all Nations. 


\section{BIBLIOGRAPHY}

\section{Primary sources}

1. Sales of Goods Act (1930)

2. Indian Contract Act (1872

3. International Sale of Goods (1980)

4. Arbitration and Conciliation Act (1996)

5. Registration Act (1908)

6. Contracts for the International Sale of Goods (1980)

7. Micro, Small and Medium Enterprises Development Act (2006)

\section{Secondary Sources}

1. Singh, Avatar, Contract \& Specific Relief, Tenth Edition 2008, Eastern Book Company

2. Bangia, R. K. Contract- 2 (sixth edition,2009)

3. Klotz, James M, International Sales Agreements, 2008, Kluwer Law International

\section{Internet Documents}

1. https://www.lawteacher.net

2. https://uk.practicallaw.thomsonreuters.com

3. https://blog.ipleaders.in

4. ranarizwanhussain.wordpress.com

5. www.legalmatch.com

6. www.legislation.gov.uk

7. www.advocatekhoj.com

8. www.ekconsultinggroup.com

9. gradestack.com

10. indiankanoon.org

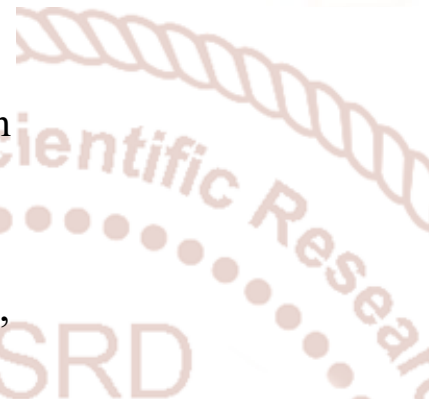

11. www.privatelawtutor.co.uk

12. viperfusion.com 